\title{
Characterization and Identification of Some Aerobic Spore- Forming Bacteria Isolated From Saline Habitat, West Coastal Region, Saudi Arabia
}

\author{
Naheda Alshammari ${ }^{1 *}$, Fatma Fahmy ${ }^{1}$, Sahira Lari ${ }^{2}$ and Magda Aly ${ }^{1,3}$ \\ ${ }^{I}$ Biology Department, Faculty of Science, King Abdulaziz University, Jeddah, Saudi Arabia, \\ ${ }^{2}$ Biochemistry Department, Faculty of Science, King Abdulaziz University, Jeddah, Saudi Arabia, \\ ${ }^{3}$ Botany Department, Faculty of Science, Kafr el-Sheikh University, Egypt
}

\begin{abstract}
Ten isolates of aerobic endospore- forming moderately halophilic bacteria were isolated fromsaline habitat at the west coastal region near Jeddah. All isolates that were Gram positive, catalase positive andshowing different colony morphology and shapes were studied. They were mesophilic, neutralophilic, with temperature range $20-40^{\circ} \mathrm{C}$ and $\mathrm{pH}$ range 7-9. The isolates were separating into two distinct groups facultative anaerobic strictly aerobic. One isolate was identified as Paenibacillus dendritiformis, two isolates as Bacillus oleronius, two isolates as $P$. alvei, three isolates belong to $B$. subtilis and B. atrophaeus, and finally two isolates was identified as Bacillus sp. Furthermore, two aerobic endospore-forming cocci, isolated from salt-march soil in Germany were tested for their taxonomical status and used as reference isolates and these isolates belong to the species Halobacillus halophilus. Chemotaxonomic characteristics represented by cell wall analysis and fatty acid profiles of some selected isolates were studied to determine the differences between species.
\end{abstract}

Keywords: Halobacillus, Bacillus, spore, mesophilic, physiological, morphological

\section{Introduction}

Aerobic spore-forming bacteria represent a major microflora in many natural biotopes and play an important role in ecosystem development. These bacteria are able to transform many chemical compounds including industrial pollutants. In the past, most of strains belong to the heterogeneous group of aerobic, endospore-forming, Gram-positive bacteria and were classified in genus Bacillus (Berkeley and Goodfellow, 1981; Claus and Berkeley, 1986) and Sporosarcina (Claus et al., 1983, 1984). However, later this group became larger and included other genera such as Amphibacillus and Sulfobacillus (Holt et al., 1994). Classification of genus Bacillus that included heterogeneous isolates with similar phenotypic characteristics, nutrition requirements, and 33.8- 60.4\% guanine and cytosine ratio (Fahmy et al., 1985) is very important. According to the phenotypic classification, 368 strains of the genus Bacillus were classified into 79 different taxonomic groups (Priest et al., 1988). Moreover, recent phenotypic and evolutionary phylogenetic taxonomic studies resulted in classifying a number of new genera into this group including Filobacillus (Schlesner et al., 2001), Geobacillus, Gracilibacillus and Salibacillus (Wain et al., 1999), Halobacillus (Spring et al., 1996) Jeotgalibacillus and Marinibacillus (Yoon et al., 2001b), Ureibacillus (Fortina et al., 2001), Virgibacillus (Heyndrickx et al., 1998), Alicyclobacillus (Wisotzkey et al., 1992), Paenibacillus (Ash et al., 1993), Aneurinibacillus, (Shida et al., 1996) and Brevibacillus (Shida et al., 1996). The genus Sporosarcina is characterized by spherical bacteria arranged into groups of four, in cubes consisting of eight cells, or other multiple of four arrangements and this genus contained two species, $S$. ureae and S. halophila (Claus and Fahmy, 1986) but based on a study of the evolutionary traits, S. halophila was re-classified under the genus Halobacillus (Spring et al., 1996). In 2001, S. aquimarina was isolated from seawater in Korea (Yoon, et al. 2001a) and was added to genus Sporosarcina based on chemotaxonomy and evolutionary which based on amino acids analysis and 16S rRNA sequence data (Busse et al. 1999). Three Bacillus isolates were added to genus Sporosarcina, S. globispora, S.pasteurii and S. psychrophila (Yoon et al. 2001a). In addition, S. macmurdoensis was added to the previous genus (Reddy et al., 2003). Then, the genus Sporosarcina was re-classified under the Bacillales and Planococcaceae (Garrity et al., 2002, 2004). Therefore, the investigation of these micro-organisms is highly important for microbiologists dealing with ecological studies and environment protection. The aim of this study was isolation and classification of some spore forming bacterial isolates, obtained from marine habitats, Jeddah, Saudi Arabia. 


\section{Bacterial isolation}

\section{Material And Methods}

Ten bacterial isolates from a saline habitat at the west coastal region near Jeddah, were obtained using a dilution plating technique on modified Tryptone Soy Agar(CM 0131 Oxoid), prepared with artificial seawater (Yoon et al., 2001a). Bacillus megaterium (DSM 90) and Halobacillus halophilus (DSM 2266) from Deutsche Sammlung von Mikroorganismen und Zellkulturen (DSMZ), Braunschweig, Germany, were used as reference strains.

\section{Morphological and physiological characterization:}

The morphological characters on modified Tryptone Soy Agar at $30^{\circ} \mathrm{C}$ were determined (Claus and Berkely, 1986; Smibert and Krieg, 1994). Cell morphology and motility were observed by phasecontrast microscopy while Gram staining was done as described by Salle (1961) and Malik (1992). Optimum temperature and $\mathrm{pH}$, temperature and $\mathrm{pH}$ ranges, growth under anaerobic conditions in an anaerobic jar using Oxoid gas generating kit- BR 38 (Quesada et al. , 1984), and tolerance to different concentrations of sodium chloride on nutrient agar supplemented with 2-20\% $\mathrm{NaCl}(\mathrm{w} / \mathrm{v})$ were investigated (Spring et al., 1996). The oxidase activity (Liu and Jurtshuk, 1986) and catalase activity (Whittenbury 1964, Haynes 1972) were conducted. Hydrolysis of Starch, Casein, Tyrosine and Cellulose (Lanyi, 1987) in addition to other biochemical tests using API 20E (bio Merieux) were examined (Logan and Berkeley 1981).

\section{Chemotaxonomic characterization:}

The chemical analysis of the cell wall was carried out by the methods described by Atrih et al. (1999) and Mckerrow et al. (2000). The peptidoglycan structure was determined using the method of Harper and Davis (1979). Fatty acids were extracted and prepared as described by Sasser (2001). The fatty acid analysis and identification were completed by Nelson Laboratories according to the instructions of the Microbial Identification System (MIDI).

\section{Results}

After incubation on modified Tryptone Soy Agar at $30^{\circ} \mathrm{C}$, ten isolates were obtained and named SAJ5, SAJ7, SAJ8, SAJ11, SAJ12, SAJ13, SAJ14, SAJ16, SAJ17 and SAJ19. All isolates showed different colony morphology and all cells were straight rods, mono or diplo bacilli. Some of the isolates had short chains of cells and some of them had palisade arrangement (Figure 1). All isolates were Gram-positive, motile and spore-formers while some of the isolates had swollen sporangia or had both swollen and non swollen sporangia in the same microscopic field of the pure culture (Figure 2). The spores were located in different positions, centrally, sub-terminally or terminally (Figure 3).

All isolates were mesophilic, neutralophilic, with temperature range $20-40^{\circ} \mathrm{C}$, and $\mathrm{pH}$ range $7-9$. Therefore, the temperature used for all tests was $30^{\circ} \mathrm{C}$, and $\mathrm{pH} 7$.The isolates tolerate $5-15 \%$ sodium chloride and some isolates could withstand heating till $95^{\circ} \mathrm{C}$ for $15 \mathrm{~min}$. Positive results of all the isolates were positive for catalase, oxidase, starch hydrolysis and tyrosine decomposition. Negative results were for lysis by $3 \% \mathrm{KOH}$, hydrolysis of cellulose, phenylalanine deaminase, VP test, acid production from raffinose and arginine dihydrolase, Lysine decarboxylase, Ornithine decarboxylase, Tryptophane desaminase, indole and $\mathrm{H}_{2} \mathrm{~S}$ production. Different results were recorded for gelatin and casein hydrolysis, nitrate reduction, Acid production fromD-Glucose (Table 1).

According to the ability to grow under anaerobic conditions, the isolates could be separated into two groups. Group 1 represents those isolates that grow under anaerobic conditions, isolates SAJ5, SAJ3 and SAJ19. This group was further subdivided into two subgroups according to $\mathrm{pH}$ range, and growth on nutrient agar containing $\mathrm{MgCl}_{2}$. Group 2 includes those which were strictly aerobic isolates SAJ7, SAJ8, SAJ11, SAJ12, SAJ14, SAJ16 and SAJ17. Further classification of group 2 according to temperature range, heat resistance of spore, and sodium chloride tolerance resulted in separating these seven isolates into six subgroups. By applying the described biochemical tests and according to the results of the other routine phenotypic tests this classification is confirmed. Using the taxonomical key for identification of this group of aerobic endospore-forming bacteria (Reva et al., 2001), with its new proposed and established genera and species, eight isolates from the present rod-shaped ones could be identified. The isolate SAJ5 identified as Paenibacillus dendritiformis. Two isolates SAJ7 and SAJ8 were identified as Bacillus oleronius, and other two isolates SAJ13 and SAJ19 as Paenibacillus alvei. The last three isolates SAJ11, SAJ12 and SAJ17 were identified as isolates belonging to B. subtilis and P. kobensis, according to the absence or the presence of swollen sporangia and using the keys for identification of the typical Bacillus species. For isolates SAJ14 and SAJ16, they were recorded as new isolates because they were not identical to any of the species reported in the used keys. 
Identification of the isolates SAJ5, SAJ14, SAJ16 and SAJ-17 in addition to the reference type strain B. megaterium (DSMZ 90) was confirmed using the analysis of their cell walls. The results revealed that the murein type of the reference type strain of $B$. megaterium DSMZ 90 showed murein type (A4 $\gamma)$. Isolates SAJ14 and SAJ16 showed the same murein type as that of B. megaterium (A4 $\gamma$ ) while, isolate SAJ17 had the same murein type with an additional amino acid (Asp). The murein type of isolate SAJ 5 was like to that of $H$. halophilus (Orn-Asp: A4ß).

Moreover, fatty acids were extracted from the isolates SAJ5, SAJ14, and SAJ17 and the results of this analysis showed agreement with the identification made in this study using the identification keys. However, the analysis of isolate SAJ14 failed to determine the type of the isolate according to all listed types in (MIDI), which agree with obtained results in this study based on the used identification key.

\section{Discussion}

Aerobic spore-forming bacteria represent by genus Bacillus are a group of bacteria that occupy diverse ecological systems and have been isolated from various habitats (Logan and De Vos, 2009). In recent years, there are 751 species in 73 Bacillus-related genera found in the world (Liu et al., 2015). Many of these names are not present in the previous keys for identification of this group. This situation causes difficulties in identification of any aerobic spore-former. This problem of taxonomical status of this group was very appealing. Especially that some researchers use different set of morphological and physiological characteristics to identification new genera or species (Reva et al., 2001). Therefore, to have a well classification and identification of this bacterial group, the chemotaxonomic methods were applied, which determined based on similarities in the chemical structure of certain compounds. One of chemotaxonomic techniques is the chemical analysis of the bacterial cell wall and identifies the muerin type which is widely used to identify and classify several species of bacteria (El-Rahman et al., 2002, Albuquerque et al., 2008, Madhaiyan et al., 2010, Dunlap et al., 2015). Furthermore, the analysis of the fatty acids is used in the identification and classification of this group. Typically, this analysis is conducted by either gas-liquid chromatography (GLC) (Ivanova et al., 2003) or by gas chromatography (Gugger et al., 2002; Ajithkumar et al., 2003). The results of the chromatography analysis can be quantitatively analyzed and electronically stored in a computer for further comparison (Stead et al., 1992). Therefore; the identification of the indeterminate bacterial isolates can be conducted by comparing these isolates against the commercial (MIDI). This microbial identification system is widely used to identify unknown bacteria (Palmisano et al. 2001, Logan et al., 2002, Groudieva et al., 2003, Balca' zar et al., 2010, Vaz-Moreira et al., 2012, Reddy et al., 2015). Finally, to confirm the identification of the isolates already denoted to particular species, or the unknowns, further experimental analyses have to take place, such as protein profiles, $\mathrm{G}+\mathrm{C} \%$ and hybridization with specific species using DNA and RNA. The results revealed that the murein type of $B$. megaterium DSMZ 90 is A4 $\gamma$ and the same results was obtained by Bricas et al. (1967) and Schleifer and Kandler (1972). Moreover, based on the high agreements between our results and the analysis conducted by Nelson labs, isolate SAJ14 can be classified as new specie. However, further investigation and more experiments need to be carried out to confirm the identification of this isolate.

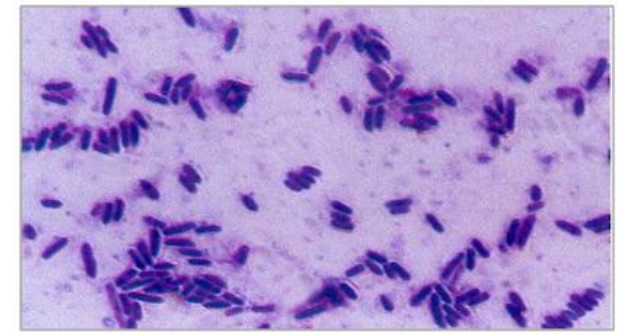

Figure 1. Light microscope (x1000) of rods and palisade shape of the isolate SAJ14

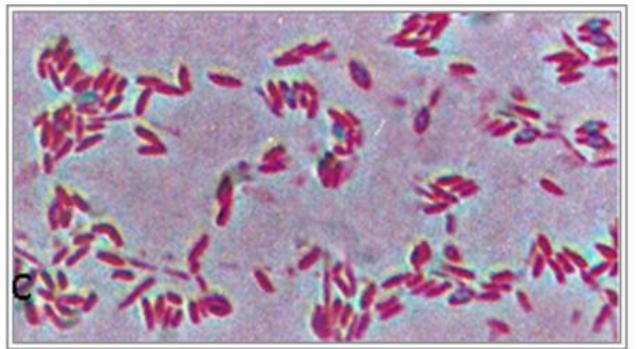

Figure 2. Light microscope (x1000) of endospores and vegetative cells of the isolate SAJ8 


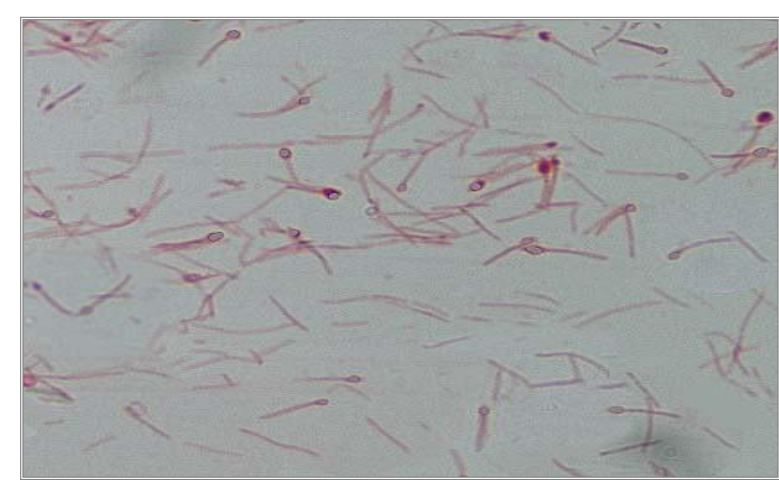

Figure3. Light microscope (x1000) of terminal endospores and vegetative cells of the isolate SAJ11.

Table1. Differential phenotypic characteristics of the tested bacterial isolates

\begin{tabular}{|c|c|c|c|c|c|c|c|c|c|c|}
\hline Character tested & SAJ-5 & SAJ-7 & SAJ-8 & 5AJ-11 & SAJ-12 & SAJ-13 & SAJ-14 & SAJ-16 & SAJ-17 & SAJ-19 \\
\hline Colony color & \multicolumn{2}{|c|}{ Orange } & & Cream & & Orange & Cream & $\begin{array}{r}\text { Light } \\
\text { orange }\end{array}$ & $\begin{array}{r}\text { Light } \\
\text { yellow }\end{array}$ & Cream \\
\hline Cell morphology & $\begin{array}{c}\mathrm{R} \\
(\mathrm{SC})\end{array}$ & $\begin{array}{c}\mathrm{R} \\
(\mathrm{DB})\end{array}$ & $\begin{array}{c}\mathrm{R} \\
(\mathrm{PA})\end{array}$ & $\begin{array}{c}\mathrm{R} \\
(\mathrm{DB})\end{array}$ & $\begin{array}{c}\mathrm{R} \\
(\mathrm{DB})\end{array}$ & $\begin{array}{c}\mathrm{R} \\
(\mathrm{PA})\end{array}$ & $\begin{array}{c}\mathrm{R} \\
(\mathrm{PA})\end{array}$ & $\begin{array}{c}\mathrm{R} \\
(\mathrm{SC})\end{array}$ & $\begin{array}{c}\mathrm{R} \\
(\mathrm{SC})\end{array}$ & $\begin{array}{c}\mathrm{R} \\
(\mathrm{DB})\end{array}$ \\
\hline Endospore location & $\mathrm{C}$ & ST & $\mathrm{C} / \mathrm{ST}$ & $\mathrm{T}$ & $\mathrm{T}$ & $\mathrm{C} / \mathrm{ST}$ & $\mathrm{C} / \mathrm{ST}$ & $\mathrm{C} / \mathrm{ST}$ & $\mathrm{T}$ & $\mathrm{C}$ \\
\hline Swollen sporangia & $\mathrm{S}$ & $\mathrm{S}$ & S & $\mathrm{S} / \mathrm{US}$ & $\mathrm{S} / \mathrm{US}$ & $\mathrm{S} / \mathrm{US}$ & $\mathrm{S}$ & $\mathrm{S}$ & $\mathrm{S} / \mathrm{US}$ & $\mathrm{S}$ \\
\hline \multicolumn{11}{|l|}{ Growth conditions } \\
\hline Anaerobic growth & + & - & - & - & - & + & - & - & - & + \\
\hline $\begin{array}{l}\text { Growth temperature } \\
\text { range }\left({ }^{\circ} \mathrm{C}\right)\end{array}$ & $10-40$ & $15-40$ & $10-40$ & $10-40$ & $15-40$ & $10-40$ & $20-45$ & $10-40$ & $10-40$ & $10-40$ \\
\hline $\mathrm{pH}$ range & $6-9$ & $6-9$ & $6-9$ & $6-10$ & $6-10.5$ & $6-10.5$ & $5-9$ & $6-10.5$ & $6-10.5$ & $6-10.5$ \\
\hline $\mathrm{NaCl}(\%)$ range & $2-15$ & $2-5$ & $2-5$ & $3-5$ & $2-7$ & $3-15$ & $2-10$ & $2-7$ & $2-7$ & $3-15$ \\
\hline
\end{tabular}

Hydrolysis of:

\begin{tabular}{cccccccccccc} 
Gelatin & + & + & + & - & - & + & - & - & - \\
Casein & + & - & - & - & - & + & - & - & + \\
$\begin{array}{c}\text { Nitrate reduction } \\
\text { Acid production from } \\
\text { D-Glucose }\end{array}$ & \pm & - & - & - & + & + & - & - & - & + \\
\hline
\end{tabular}

${ }^{*} \mathrm{R}$ : rods; SC: Short chains; PA: Palisade arrangement, DB: Diplobacilli; T:Terminal spore;

C: Central, ST: Sub-terminal spore, S: Swollen; US: Unswollen; +: Positive; \pm : Weakly positive; -: Negative

\section{References}

[1]. Abd El-Rahman, H., Fritze, D., Sproser, C.and Claus, D. (2002). Two novel psychrotolerant species, Bacillus psychrotolerans sp. nov. and Bacillus psychrodurans sp. nov., which contain ornithine in their cell walls. Int. J. Syst. Evol. Microbiol., 52: 2127-2133.

[2]. Albuquerque, L., Tiago, I., Taborda, M., Nobre, M,F., Verı'ssimo, A. and Costa, M, S. (2008). Bacillus isabeliae sp. nov., a halophilic bacterium isolated from a sea salt evaporation pond, Int. J. Syst. Evol. Microbiol, 58: 226-230.

[3]. Ash, C., Priest, F.G. and Collins, M.D. (1993). Molecular identification of rRNA group 3 bacilli (Ash, Farrow, Wallbanks and Collins) using a PCR probe test. Proposal for the creation of a new genus Paenibacillus. Antonie Van Leeuwenhoek, 64:25360 .

[4]. Atrih, A., Bacher, G., Allmaier, G., Williamson, M. P. and Foster, S.J. (1999). Analysis of Peptidoglycan Structure from Vegetative Cells of Bacillus subtilis 168 and Role of PBP 5 in Peptidoglycan Maturation, J. Bacteriol., 181: 3956-3966.

[5]. Balca'zar, J, L., Pintado, J. and Planas, M. (2010). Bacillus galliciensis sp. nov., isolated from faeces of wild sea horses (Hippocampus guttulatus). Int. J. Syst. Evol. Microbiol. 60: 892-895.

[6]. Berkeley, R. C. W. and Goodfellow, M. (1981). The aerobic Endospore-Forming Bacteria : Classification and Identification . London, New York: Academic Press. 
[7]. Busse, J., Knunbauer, M. andInführ, D. (1999). Bacterial Systematics I. Species Identification by Chemotaxonomic Methods.Protocol- Bacterial Systematics.

[8]. Claus, D. and Berkeley, R.C.W. (1986). The Genus Bacillus. Mair, N. S., Sharpe, M.E. and Holt, J.G. (eds) In: Bergey's manual of systematic bacteriology. vol. 2, pp. 1105-1127, Baltimore: Williams \& Wilkins.

[9]. Claus, D., Fahmy, F., Rolf, H. J. and Tosonoglu, N. (1984). In Validation of The Publication of New Names and New Combination Preriously Effectively Published. Int. J. Syst. Bacteriol., 34 : 270-271.

[10]. Claus, D., Fahmy, F., Rolf, H. J. and Tosunoglu, N. (1983). Sporosarcina halophila sp. nov., an obligate slightly halophilic bacterium from salt marsh soils. Syst. Appl. Microbiol. 4: 496-506.

[11]. Dunlap, C.A., Kwon, S.W., Rooney, A.P. and Kim, S.J. (2015). Bacillus paralicheniformis sp. nov., isolated from fermented soybean paste. Int. J. Syst. Evol. Microbiol., 65:3487-3492.

[12]. Fahmy, F., Flossdorf, J. and Claus, D. (1985). The DNA Base Composition of the Type Strains of the Genus Bacillus. Syst. Appl. Microbiol., 6:60-65.

[13]. Fortina, M.G., Pukall, R., Schumann, P., Mora, D., Parini, C., Manachini, P.L. and Stackebrandt, E. (2001) Ureibacillus gen. nov., a new genus to accommodate Bacillus thermosphaericus (Andersson et al., 1995), emendation of Ureibacillus thermosphaericus and description of Ureibacillus terrenus sp. nov. Int. J. Syst. Evol. Microbiol.,51: 447-455.

[14]. Garrity, G.M., Bell, J.A. and Lilburn, T.G. (2004). Bergey's Manual of Systematic Bacteriology , www.com.msu.edu/ bergeys/ april 2004-genus.pdf .

[15]. Garrity, G.M., Winters, M. and Searles, D.B. (2002). Bergey's Manual of Systematic Bacteriology. bergeys/ 2001-genus.pdf www.com.msu.edu/.

[16]. Harper, J.J., and Davis, G.H.G. (1979). Two Dimensional Thin Layer Chromatography for Amino Acid Analysis of Bacterial Cell Wall. Int. J. Syst. Bacteriol., 29:56-59.

[17]. Haynes, W.C. (1972). The catalase test. An aid in the identification of Bacillus larvae. Am. Bee J. 112:130-131.

[18]. Heyndrickx, M., Lebbe, L., Kersters, K., De Vos, P., Forsyth, G . and Logan, N. A. (1998) Virgibacillus: a new genus to accommodate Bacillus pantothenticus (Proom and Knight 1950). Emended description of Virgibacillus pantothenticus. Int. J. Syst. Bacterial. 48: 99 - 106

[19]. Holt, J.G., Krieg, N.R., Sneath, P.H.A., Staley, J.T. and Williams, S.T. (1994). Bergey's Manual of Determinative Bacteriology. 9th ed., London: Williams \& Wilkins.

[20]. Lanyi, B. (1987). Classical and rapid identification: methods for medically important bacteria. Methods Microbiol., 19: 1-67.

[21]. Liu, B., Wang, J.P., Yu, Z.N. and Tao, T.S. (2015). List of species name for the Bacillus like bacteria. J. Agric. Sci., 30:3859.

[22]. Liu, J.K. and Jurtshuk, JR. P. ( 1986 ) N,N,N'-N' - Tetramethyl-p-Phenylenediamine-Dependent Cytochrome Oxidase Analyses of Bacillus Species. In. J. Syst. Bacteriol., 36: 38-46.

[23]. Logan, N.A. and De Vos, P. (2009). Genus Bacillus. In Bergey's Manual of Systematic Bacteriology, vol. 3, pp. 21-128. Edited by P. De Vos, G. Garrity, D. Jones, N.R. Krieg, W. Ludwig, F.A. Rainey, K.H. Schleifer\& W.B. Whitman. New York: Springer.

[24]. Logan, N.A. and Berkeley, R.C.W. (1981) Classification and identification of members of the genus Bacillus using API tests, in : Berkeley, R. C. W. and Goodfellow, M. (eds.) The aerobic Endospore-Forming Bacteria: Classification and Identification, pp. 105-140, London: Academic Press.

[25]. Madhaiyan, M., Poonguzhali, S., Wo Kwon, S.and Min Sa, T. (2010). Bacillus methylotrophicus sp. nov., a methanol utilizing plant-growth-promoting bacterium isolated from rice rhizosphere soil. Int. J. Syst. Evol. Microbiol., 60:2490-2495.

[26]. Malik, K.A. (1992). Technical Information for Culture Collections Curators in developing Countries, Braunschweig: Unesco/ WFCC Committee.

[27]. McKerrow, J., Vagg, S., McKinney, T., Seviour, E.M., Maszenan, A.M., Brooks, P. and Seviour, R.J. (2000) A simple HPLC method for analyzing diaminopimelic acid in cell walls of Gram-positive bacteria. Lett. Appl. Microbiol., 30: 178-182.

[28]. Priest, F.G., Goodfellow, M. and Todd, G. (1988) A numerical classification of the genus Bacillus. J. Gen. Microbiol., 134: 1847-1882.

[29]. Quesada, E., Ventosa, A., Ruiz-Berraquero, R. F. and Ramos-Cormenzana, A.(1984) Deleyahalophila , a New Species of Moderately Halophilic Bacteria. Int. J. Syst. Bacteriol., 34: 287-292.

[30]. Reddy, G. S. N., Matsumoto,G. I. and Shivaji, S. (2003). Sporosarcina macmurdoensis sp. nov., from a cyanobacterial mat sample from a pond in the McMurdo Dry Valleys, Antarctica. Int. J. Syst. Evol. Microbiol., 53:1363-1367.

[31]. Reddy, S,V., Thirumala, M., and Farooq, M. (2015). Bacillus caseinilyticus sp. nov., an alkali- and thermotolerant bacterium isolated from a soda lake. Int. J. Syst. Evol. Microbiol., 65: 2441-2446.

[32]. Salle, A. J. (1961) Laboratory Manual on Fundamental Principles of Bacteriology. New York : McGraw-Hill.

[33]. Sasser, M. (2001). Identification of Bacteria by Gas Chromatography of Cellular Fatty Acids, Technical note no: 101. www.midi-inc.com.

[34]. Schlesner, H., Lawson, P. A., Collins, M. D., Weiss, N., Wehmeyer, U., Völker, H. and Thomm, M. (2001) Filobacillus milensis gen. nov., sp. nov., a new halophilic spore-forming bacterium with Orn-D-Glu-type peptidoglycan. Int. J. Syst. Evol. Microbiol., 51: 425-431.

[35]. Shida, O., Takagi, H., Kadowaki, K. and Komagata, K. (1996). Proposal for Two New Genera, Brevibacillus gen. nov., and Aneurinibacillus gen. nov. Int. J Syst. Bacteriol., 46: 939 - 946.

[36]. Smibert, R. M. and Krieg, N. R. (1994). Phenotypic Characterization. in: Gerhardt, P., Murray, R. G. E., Wood, W. A. and Krieg, N.R. (eds.). Methods for General and Molecular Bacteriology, pp: 21-40. Washington D.C: American Society for Microbiology.

[37]. Spring, S., Ludwig, W., Marquez, M.C., Ventosa, A. and Schleifer, K.H. (1996). Halobacillus gen. nov., with Descriptions of Halobacillus litoralis sp. nov., and Halobacillus trueperi sp. nov., and Transfer of Sporosarcina halophila to Halobacillus halophilus comb. nov. Int. J. Syst. Bacteriol., 46: 492-496.

[38]. Vaz-Moreira, I., Figueira, V., Lopes, A, R., Cunha, A.L., Sproer, C., Schumann, P., Nunes, O.C. and Manaia, C. (2012). Bacillus purgationiresistans sp. nov., isolated from a drinking-water treatment plant. Int. J. Syst. Evol. Microbiol., 62: 71-77.

[39]. Wainq, M., Tindall, B.J., Schumann, P. and Ingvorsen, K. (1999). Gracilibacillus gen. nov., with description of Gracilibacillus halotolerans gen. nov., sp. nov.; transfer of Bacillus dipsosauri to Gracilibacillus dipsosauri comb. nov., and Bacillus salexigens to the genus Salibacillus gen. nov., as Salibacillus salexigens comb. nov. Int. J. Syst. Bacteriol., 49: 821831.

[40]. Whittenbury, R. (1964). Hydrogen peroxide formation and catalase activity in the lactic acid bacteria. J. Gen. Microbiol., 35:13-26. 
[41]. Wisotzkey, J.D., Jurtshuk, P., Fox, Jr, G.E., Deinhard, G. and Poralla, K. (1992). Comparative sequence analyses on the 16S rRNA (rDNA) of Bacillus acidocaldarius, Bacillus acidoterrestris, and Bacillus cycloheptanicus and proposal for creation of a new genus, Alicyclobacillus gen. nov. Int. J. Syst. Bacteriol., 42: 263-269.

[42]. Yoon, J.H., Weiss, N., Lee, K.C., Lee, I. S., Kang, K.H. and Park, Y.H. (2001 b) Jeotgalibacillus alimentarius gen. nov., sp. nov., a novel bacterium isolated from jeotgal with L-lysine in the cell wall, and reclassification of Bacillus marinus Rüger 1983 as Marinibacillus marinus gen. nov., comb. nov. Int. J. Syst. Evol. Microbiol., 51: 2087-2093.

[43]. Yoon, J.H., Lee, K.C., Weiss, N., Kho,Y.H., Kang, K.H. and Park, Y.H. (2001a). Sporosarcina aquimarina sp. nov., a bacterium isolated from seawater in Korea, and transfer of Bacillus globisporus (Larkin and Stokes 1967), Bacillus psychrophilus (Nakamura 1984) and Bacillus pasteurii (Chester 1898) to the genus Sporosarcina as Sporosarcina globispora comb. nov., Sporosarcina psychrophila comb. nov. and Sporosarcina pasteurii comb. nov., and emended description of the genus Sporosarcina. Int. J. Syst. Evol. Microbiol., 51: 1079-1086. 